\title{
SWOT - Analysis as the Main Tool of Strategic Management of Agricultural Enterprise
}

\author{
Zarema Mandrazhi* \\ Crimean Engineering and Pedagogical University named after Fevzi Yakubov, Simferopol, per. \\ Uchebniy, 8, Republic of Crimea, Russian Federation
}

\begin{abstract}
The article deals with theoretical-applied aspects of using of SWOT- analysis in the sphere of strategic management at agricultural enterprises. The analysis of strengths and weaknesses of agricultural enterprise, its strategic opportunities and threats has been implemented. On the basis of the implemented analysis constituting components of strategy of development aimed to provision of competitiveness of agricultural enterprise at the agrarian market and perspectives of development in future have been identified.
\end{abstract}

\section{Introduction}

In modern economic conditions in which agrarian enterprises are functioning such tendencies as uncertainly of their internal environment and instability of macroeconomic situation are specific. Therefore, with the aim of adaptation to the changes of external factors agrarian enterprise has to use the modern methods of the strategic planning in the activity. The main tool of practical realization of new approaches to managing agricultural enterprise is using modern technologies of economic analysis, among which SWOT analysis takes an important place. It is SWOT - analysis that enables to make profound investigation of external of macro environment and internal state of agrarian enterprise (microenvironments), to define tendencies in the changes of external environment, opportunities and reserves of further development.

It has been marked in research works of scientists [1-8] that SWOT - analysis is the basis for evaluation of effective directions of activity of establishment, revealing favorable opportunities and threats on the side of surrounding market environment. However, in spite of the great number of research investigations on the given topic and the broad circle of considered problems, a number of unsolved questions has been left from the position of their use in the strategic analysis of agricultural enterprises. The necessity of using new approaches in strategic analysis of agrarian sector and a number of specific aspects demand further scientific investigations and research. Thereby the aim of this article is investigation of opportunities of implementing of SWOT - analysis for defining main reference points of development of enterprises of agrarian sphere.

Agricultural enterprise like any other organization interacts with surrounding environment with the help of a great number of various communications and

\footnotetext{
* Corresponding author : zaremamandrazhi@gmail.com
} 
interdependence. For this reason, effective and successful functioning of agricultural enterprises in market environment provides the opportunity of their adaptation to the external changing conditions. Thus for their success at the market so-called strategic vision which reflects the essence of business and directs all its efforts to achieving higher results than results of nearest competitors, should be used. Therefore, the main problem is the problem of evaluation od industrial and marketing activity of enterprise, determinations its effectiveness by means of such a methodic, as SWOT - analysis which is basis of formation of development strategy. For this reason, in theory and practice of agrarian management, marketing and logistics more frequently analytical approaches, which make possible evaluation of current state of enterprise and perspectives of its development, method of SWOT - analysis. (SWOT is abbreviation from English words «strengths» (strong sides), «weaknesses» (weak sides), «opportunities» (facilities), «threats» (dangers)). In scientific literature one can observe the following synonyms of this word, as matrix of TOWS or method of WOTS - UP.

\section{Material and methods}

SWOT - analysis has the aim of identification, determination and selection of main priorities, problems and opportunities provide by external environment, within which the company functions, as well as ones connected with development of company its internal activity. SWOT - analysis is the initial stage and basis of formation of strategy of development at the enterprise. It also acts as an intermediate link between formulation of mission of the enterprise and defining specific strategic goals and objectives. Specification of goals and objectives is impossible without receiving clear evaluation of potential of the enterprise and situation in the market.

In this regard the main task of SWOT - analysis is provision to manager necessary information for reasonable choice of strategy taking into account subsequent changes in external and internal environments of functioning of enterprise. Formation of portfolio of strategies of enterprise is complicated and labour - consuming process, therefore it should be realized in certain logical sequence: investigation of macro environment, development of profile and revealing of threats and opportunities; research of microenvironment, development of profile and exposure of both dangers and opportunities (on the side of factors of direct environment) as well as strengths and weaknesses (on the side of factors of internal environment); development of general profile of environment and matrix of SWOT - analysis; development of profile of positioning of elements and formation of portfolio of strategies of development.

The methodology of carrying out of SWOT - analysis foresees implementation of several stages. At the first stage strengths and weaknesses of enterprise are defined. For this purpose, list of parameters by means of which evaluation of internal environment of enterprise will be implemented, is complied.

At the second stage market opportunities and threats are determined. This stage enables to evaluate situation out of the enterprise and understand whether there are opportunities, and which threats should be taken into consideration.

At the third stage matching of strengths and weaknesses of the enterprise with opportunities and threats of market is implemented. For matching opportunities of the enterprise with market conditions and generalization the results of SWOT - analysis matrix SWOT is used. 


\section{Theory}

In an agrarian sphere every enterprise needs own strategy which would give it opportunity to neutralize threats and weak aspects, from one side, and from another side, to realize all its facilities and advantages. Regarding above-mentioned theoretical aspects on the example of activity of agricultural enterprise of the Simferopol region of Republic of Crimea the analysis of strengths and weaknesses of the given enterprise, as well as its external opportunities and threats has been implemented (table. 1). After compilation of matrix of SWOT of the enterprise has to answer the following questions:

- whether the enterprise has strengths or competitive advantages, on which the strategy could be based;

- whether weaknesses of the enterprise make it vulnerable in competitive struggle and/or deprive the enterprise of opportunity to use certain perspectives of the branch; which weaknesses must strategy overcome;

- what opportunities in external environment may the enterprise use with its resources and experience in order to expect success;

- what threats must the company management be afraid of; which strategic changes has it to introduce to supply reliable protection.

Table 1. Matrix of SWOT - analysis of agricultural enterprise for choosing strategy of development

\begin{tabular}{|l|l|}
\hline \multicolumn{1}{|c|}{ Strengths } & \multicolumn{1}{c|}{ Weakness } \\
\hline Sufficient popularity & Narrow range of productions \\
\hline Image in the market & Non-compliance of supply schedule \\
\hline Focusing on a consumer, on his needs & Average level of prices \\
\hline High control of quality & Imperfect structure of management \\
\hline High profitability & Underload of production capacities \\
\hline Growth of working capital & Narrow specialization \\
\hline Competitive price policy & $\begin{array}{l}\text { Detachment of stuff from administrative decision } \\
\text { making }\end{array}$ \\
\hline Modern technologies of production & Dependence on raw material and component parts \\
\hline Reasonable strategy in activity sphere & Outdated equipment \\
\hline & \\
\hline Improvement of production technology & Increase in taxes and duties \\
\hline Steady demand for products & Price reduction \\
\hline Reduction in taxes and duties & Increase of inflation rates \\
\hline $\begin{array}{l}\text { Reduction of price and raw material and } \\
\text { materials }\end{array}$ & Strengthening of legislation \\
\hline Jack of foreign competitors & Decline in living standards of people \\
\hline Not fully satisfied demand for products & Change in purchasing benefits \\
\hline State support for small enterprises & Appearance of substitution goods \\
\hline Improvement in living standards of people & Exchange rate volatility \\
\hline Improvement of management & Unfavorable economic situation in the country \\
\hline Devastation and retreat of firms -producers & Increasing competition \\
\hline Prices level Increase & Appearance of new producers \\
\hline Free entry to the market & Appearance of principally new product \\
\hline Coverage of new segments of market & Non-compliance with the supply schedule \\
\hline Sales organization & Deterioration of the political situation \\
\hline
\end{tabular}

If the company management is not aware of strengths and weaknesses, does not imagine external opportunities and does not suspect threats, is not able to define pair combinations between these elements, they cannot develop strategy which would meet the state of enterprise. Therefore, compilation of matrix SWOT is necessary component of strategic 
evaluation of present state of enterprise. According to the results of SWOT - analysis while choosing strategies of activity the agrarian enterprise has to analyse the following factors:

- the state of agrarian branch and position of household on it;

- attractiveness of the market;

- strategies of competitors;

- competitive advantages of the enterprise;

- goals and mission of the enterprise;

- potential of the enterprise;

- specificity of products which is produced or will be produced;

- production and sales costs;

- interests of management and workers;

- quality and qualification of the stuff of the enterprise;

- degree of dependence on external environment;

- time factor;

- financial resources of the enterprise;

- risk level.

The final stage of strategy development of agrarian enterprise is development of operative strategies. Operative strategy is formed by primary subdivision of enterprise, in particular: workshop, team, farm, plot. Thus, everyday activity of subdivision of agrarian enterprise with a strategic orientation should be of two kinds:

- strategic fore of activity (provision of common strategic goals and tasks of the enterprise and subdivision, i.e. provision of future profitability);

- operative activity (provision of the rational use of resources, i.e. provision of current profitability).

Typical strategic plan for examined enterprise may include:

- basic information about the enterprise;

- main results of SWOT - analysis of the enterprise, namely opportunities, threats, strengths and weaknesses;

- mission and strategic goals of enterprise;

- corporate basic strategy of enterprise;

- competition strategies;

- functional strategies;

- operating strategies;

- main programs, projects and budgets of realization of strategic plan;

- indicators of strategic plan as reference-points for achieving their performance of strategic goals of enterprise.

After these actions duty tasks concerning their performance appear:

1) coordinate strategic actions with operative;

2) work out programs and projects, which will be implemented within strategy and procedure for evaluation, choice and realization of projects (in case of necessity);

3) make tactics of overcoming resistance to strategic changes;

4) bring organizational structure of agrarian enterprise into conformity with strategy;

5) bring organizational culture of enterprise, style of management, etc. into conformity with strategy.

\section{Results}

In the context with set out material the following conclusions can be done:

1) Implementation of SWOT - analysis is very important for carrying out strategic planning at the agrarian enterprise as its methodic - is an effective and available means of evaluation of state of problematic and managerial situation in the organization. It enables to 
systematize problematic situations; to understand better the structure of resources which should be basis of improvement activity and development of company in perspective; to track general state of external business-environment; to distinguish and use new potential opportunities faster, then competitors; to choose effective directions of development and avoid threats; to make informed decisions, concerning development of agribusiness.

2) Implementing of method of SWOT - analysis gives the opportunity to establish lines of connection between strengths and weaknesses, which are inherent to the given enterprise with external opportunities and threats. Thus, while planning of measures on increase of competitiveness of agrarian enterprise it is necessary to match internal opportunities (its strengths and weaknesses) and external situation (partly reflected in opportunities and threats). Therefore, strategic balance, that is combination of negative and positive factors which influence the activity of enterprise from the outside as well as from inside, helps to evaluate correctly opportunities which are open before organization.

3) Implemented SWOT - analysis enables to determine that agrarian enterprises have to seek to strengthen competitive positions regarding those factors which are opportunities, with simultaneous liquidation of weak points. In domestic practice of conducting business the sphere of implementing strategic approach to management of agricultural enterprise remains quite limited. The main reason of it is insufficient investigation of methodological problems of strategic analysis and management in agrarian sphere, in particular using SWOT - analysis, which testifies to the necessity of their additional investigation.

\section{References}

1. Ommani A. R. SWOT analysis for farming system businesses management: Case of wheat farmers of Shadervan DistrictShoushtar Township, Iran, 2011, V. 5, №. 22, 94489454.

2. Nuga B. O., Asimiea A. O. SWOT Analysis of the Nigerian Agricultural Sector, IOSR Journal of Agriculture and Veterinary Science Ver. II, 2015, v. 8, №. 4, 2319-2372.

3. Zhang Q. et al. Agricultural SWOT analysis and wisdom agriculture design of chengdu, Journal of Physics: Conference Series. - IOP Publishing, 2017, v. 887, №. 1, 012009.

4. Sahoo P. P. et al. SWOT Analysis of Agriculture in Kandhamal District of Orissa, India, J. Curr. Microbiol. App. Sci., 2018, v. 7, №. 8, 1592-1597.

5. Qiaoqiao R. E. N. Development Strategy of Agricultural Enterprises Based on SWOT Analysis [J], Problem of Agricultural Economy, 2005, v. 4.

6. Qi L. Discussion on the Strategy and Countermeasure of Agricultural Enterprise, Journal of Anhui Agricultural Sciences, 2006, v. 34, №. 5, p 987.

7. Gürel E., Tat M. SWOT analysis: a theoretical review //Journal of International Social Research, 2017, v. 10, №. 51.

8. Helms M. M., Nixon J. Exploring SWOT analysis-where are we now?, Journal of strategy and management, 2010. 